\title{
Low NOx Combustion of DME by Means of Flue Gas Recirculation"
}

\author{
Ryosuke MATSUMOTO**, Mamoru OZAWA ${ }^{* *}$, Shinya TERADA ${ }^{* *}$ \\ and Takenori IIO** \\ **Department of Mechanical Engineering, Kansai University, \\ 3-3-35 Yamate-cho, Suita, Osaka 564-8680, Japan \\ E-mail: matumoto@kansai-u.ac.jp
}

\begin{abstract}
This study focuses on the fundamental characteristics of DME (Dimethyl Ether) combustion aiming at development of low-NOx combustion technology with flue gas recirculation, FGR. The flue gas is recirculated into the combustion chamber to reduce the oxygen concentration and to suppress the combustion gas temperature, so that NOx emission is significantly reduced. The fuel gas recirculation at high mixing ratio, however, may lead to unstable combustion of conventional fuels, methane or city gas. On the other hand, DME has very high potential of applicability for the flue gas recirculation even at high mixing ratio because of its high burning velocity and low ignition temperature. Combustion tests were conducted with laboratory-scale $11 \mathrm{~kW}$ combustor. The maximum FGR ratio is $85 \%$ at the initial air ratio of 1.5 with preheated diluted air about $600 \mathrm{~K}$. The NOx emission reduced to $13 \mathrm{ppm}$ at $0 \%-\mathrm{O}_{2}$, which corresponds to about $9 \%$ of $\mathrm{NOx}$ emission at $\mathrm{FGR}=0 \%$. The stable combustion is sustained even in the low oxygen concentration by preheating diluted-air up to near the auto-ignition temperature of DME. Finally, the effect of the flue gas recirculation on the NOx and CO emission is discussed with reference to the industrial-scale water-tube boilers.
\end{abstract}

Key words: DME (Dimethyl Ether), FGR (Flue Gas Recirculation), Diffusion Combustion, Water-Tube Boiler

\section{Introduction}

Increasing attention has been focused on a new alternative fuel, DME (Dimethyl Ether), from the energy security and the environmental aspects. DME is a new synthetic fuel and the most simple ether compound, expressed by the chemical formula, $\mathrm{CH}_{3} \mathrm{OCH}_{3}$. Recently, the direct synthesis process of DME from $\mathrm{CO}$ and $\mathrm{H}_{2}$ are being reformed from the coal gasification $^{(1)}$. Thus, DME can be produced from any kinds of carbon resources, such as natural gas, coals and coal-bed methane associated in the coal mine.

The physical properties of DME are listed in Table ${ }^{(2)}$. DME does not contain sulfur component and is quite suitable for diesel engine because of high cetane number and no emission of suspended particle matters. Adiabatic flame temperature is sufficiently high, but DME has rather low ignition temperature with high burning velocity compared with propane and methane. This fact causes a difficulty in the use of pre-mixed system for lowNOx combustion. In order to develop combustion technology of DME for boilers and gas turbines, it is essential to introduce new and alternative concept for low-NOx combustion ${ }^{(3)}$.

This study focuses on the fundamental characteristics of DME combustion aiming at the development of low-NOx combustion technology with flue gas recirculation, FGR. The concept of the external flue gas recirculation is illustrated in Fig.1. The flue gas is recirculated into the combustion chamber to reduce the $\mathrm{O}_{2}$ concentration and to cause the 
Table 1 Physical properties of DME.

\begin{tabular}{|c|c|c|c|}
\hline Property & DME & Propane & Methane \\
\hline Chemical Formula & $\mathrm{CH}_{3} \mathrm{OCH}_{3}$ & $\mathrm{C}_{3} \mathrm{H}_{8}$ & $\mathrm{CH}_{4}$ \\
\hline Boiling point, $\mathrm{K}$ & 248 & 231 & 112 \\
\hline Liquid density, g/cm & 3.67 & 0.49 & N.A. \\
\hline Gas specific gravity relative to air & 1.59 & 1.52 & 0.55 \\
\hline Saturated vapor pressure, atm at $298.15 \mathrm{~K}$ & 6.1 & 9.3 & 246 \\
\hline Ignition temperature, $\mathrm{K}$ & 623 & 743 & 923 \\
\hline Cetane number & $55-60$ & 5 & 0 \\
\hline Net calorific value, $\mathrm{MJ} / \mathrm{m}^{3} \mathrm{~N}$ & 59.5 & 91.3 & 36 \\
\hline Net calorific value, $\mathrm{MJ} / \mathrm{kg}$ & 28.9 & 46.5 & 50.2 \\
\hline Adiabatic flame temperature, $\mathrm{K}$ & 2227 & 2250 & 2236 \\
\hline Burning velocity, $\mathrm{cm} / \mathrm{s}$ & 50 & 43 & 37 \\
\hline Stoichiometric ratio, $\mathrm{m}^{3} / \mathrm{m}^{3}$ & 14.3 & 23.8 & 9.52 \\
\hline
\end{tabular}

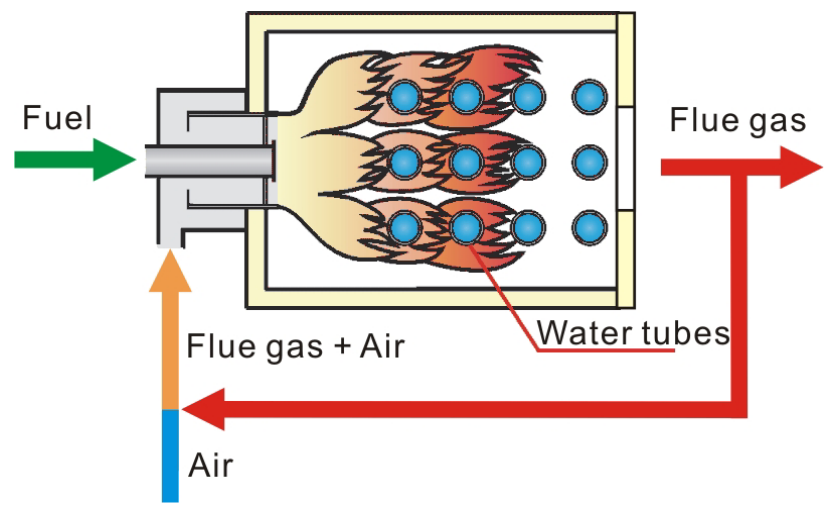

Fig. 1 Schematic view of external flue gas recirculation.

slow heat release, so that NOx emission is significantly reduced. The fuel gas recirculation at high mixing ratio, however, may lead to unstable combustion of conventional fuels, methane or city gas. On the other hand, DME has, however, very high potential of applicability of flue gas recirculation even at the high mixing ratio because of its high burning velocity and low ignition temperature.

In this study, the combustion tests were conducted with laboratory-scale $11 \mathrm{~kW}$ combustor, where $\mathrm{O}_{2}$ concentration and temperature of the combustion air was systematically regulated, so that the flue gas recirculation at various mixing ratios was simulated. The blow-off limits and the flue gas concentration were measured, and these results are compared with that of the 13A city gas. Finally, an effect of flue gas recirculation on the NOx and $\mathrm{CO}$ emission is discussed with reference to the industrial-scale $700 \mathrm{~kW}$ and $7 \mathrm{MW}$ demonstration boilers.

\section{2. $11 \mathrm{~kW}$ Laboratory-scale Combustion Test}

\subsection{Experimental Apparatus}

Figure 2 shows the experimental setup of the $11 \mathrm{~kW}$ combustor. The flow rate of the fuel gas supplied at room temperature was measured by a volumetric flow meter. The purity of the DME gas is $99.9 \%$. The city gas $13 \mathrm{~A}$ consists of $88 \%$ of methane, $6 \%$ of ethane, $3 \%$ of propane and $3 \%$ of butane and its low heating values is $41.6 \mathrm{MJ} / \mathrm{m}^{3} \mathrm{~N}$. To simulate the flue 


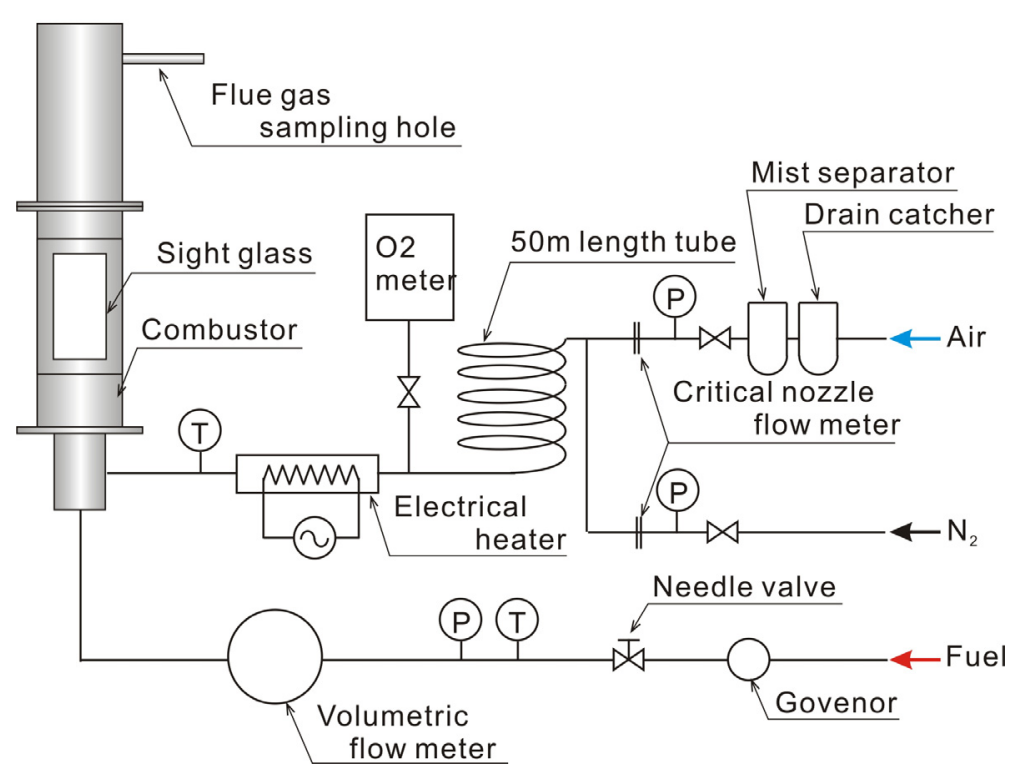

Fig.2 Experimental setup of $11 \mathrm{~kW}$ combustion test.

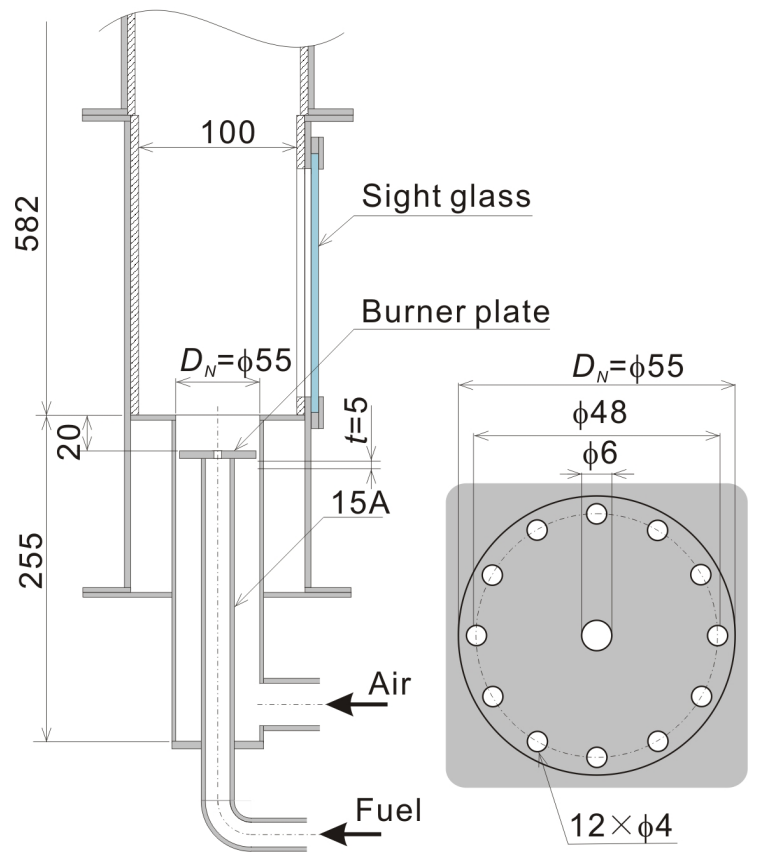

Fig.3 11kW diffusion combustor.

gas recirculation, the oxygen concentration and the temperature of combustion air were controlled by diluting with nitrogen gas preheated up to the predetermined temperature with an electrical heater. Air and nitrogen flow rates were regulated by means of a critical flow nozzle, and were well-mixed in the course of $50 \mathrm{~m}$-length tube. The oxygen concentration of the combustion air was measured by the $\mathrm{O}_{2}$ meter.

The combustor, shown in Fig.3, consists of the multi-port diffusion burner and the combustion chamber. The multi-port diffusion burner was designed by the authors to achieve well-mixed condition of fuel gas, steady and strong re-circulation followed by stable combustion and small but uniformly distributed flames ${ }^{(4)}$. The fuel gas was issued from the center hole and the combustion air was from small multiple ports placed around the fuel port. The combustion chamber has a cross-section of $100 \mathrm{~mm} \times 90 \mathrm{~mm}$ and $582 \mathrm{~mm}$ in height. At the bottom of chamber, the diffusion burner is installed. All the inner walls of the 
chamber are covered with fireproof materials. All the metallic parts of the setup consist of SUS304.

The combustion gases were sampled at $530 \mathrm{~mm}$ from the burner exit by using a watercooled sampling probe, and were analyzed with the gas analyzer (Horiba Corp. PG-235a). The CO, NOx, and $\mathrm{O}_{2}$ concentrations were measured by infrared absorption, chemiluminescence, and zirconia oxygen sensor, respectively. The gas temperature was measured by R-type thermocouple at the same position as the gas sampling.

\subsection{Results and discussion}

Figure 4 shows the NOx and $\mathrm{CO}$ concentrations of the flue gas as a function of the air ratio $\lambda$ without the flue gas recirculation. The air ratio $\lambda$ is defined as the ratio of air volume relative to the stoichiometric volume of air, i.e. the inverse of the equivalence ratio. The air ratio is approximately related to the $\mathrm{O}_{2}$ concentration of the flue gas by $\lambda=21 /\left(21-\mathrm{O}_{2}[\%]\right)$. The NOx emission decreases with increasing the air ratio, while the $\mathrm{CO}$ concentration decreases first drastically and then turns to increase. The CO concentration is sufficiently low at the range of 1.5 to 2.5 of the air ratio $\lambda$. The NOx emission is around $100 \mathrm{ppm}$ at $\lambda=1.5$ in DME combustion, which is higher than that of the city gas. The combustion tests with the simulated flue gas recirculation were carried out based on the air ratio at 1.2 and 1.5 , as a typical value considering industrial applications.

Figures 5 and 6 show the results of the city gas and DME combustion tests with flue gas recirculation. Experiments were carried out by changing the flow rate of nitrogen gas, which corresponds to the flue gas recirculation ratio, FGR ratio, defined as follows;

$$
\begin{aligned}
\text { FGR ratio } & =\frac{\text { Flow rate of recirculation flue gas }}{\text { Air flow rate }} \\
& =\frac{21 \%-\text { Diluted air } \mathrm{O}_{2} \%}{\text { Diluted air } \mathrm{O}_{2} \%-\text { Flue gas } \mathrm{O}_{2} \%}
\end{aligned}
$$

In this experiment, the FGR ratio is estimated from the measured $\mathrm{O}_{2}$ concentrations of the flue gas and the diluted combustion air, i.e., $\mathrm{O}_{2}$ concentration of the combustion air.

Figure 5 shows the combustion test of the city gas at the air ratio $\lambda=1.5$. The NOx concentration decreased successively with increasing the FGR ratio, while the flame blowoff occurred at $20 \%$ of FGR ratio when the inlet temperature of the combustion air was at

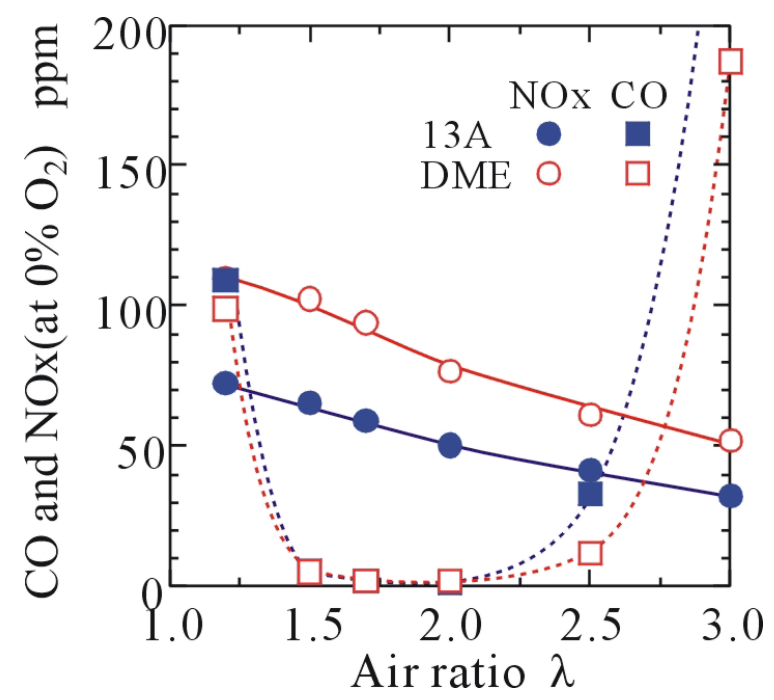

Fig.4 Flue gas concentrations of $11 \mathrm{~kW}$ combustor without flue gas recirculation at inlet air temperature of $300 \mathrm{~K}$. 
$300 \mathrm{~K}$.

By imposing the flue gas recirculation, the low oxygen concentration causes the slow heat release in the combustion chamber. The flame temperature shows relatively mild temperature distribution and the local hot spot is avoided from the flame ${ }^{(5)}$. Thus, the flue gas recirculation is an effective method to reduce the NOx emission. However, combustion with the low-oxygen concentration usually becomes unstable. By preheating the diluted air to $600 \mathrm{~K}$, the stable combustion can be achieved and the flame blow-off extended to at $50 \%$ of FGR ratio, as shown in Fig.5. In the actual flue gas recirculation, the combustion air is preheated by mixing with the high temperature flue gas.

On the DME combustion, the blow off limitation is extended to the higher FGR ratio than that of the city gas, as shown in Fig.6. The blow-off occurred at 50\% of FGR ratio for $300 \mathrm{~K}$. By preheating the diluted air to $600 \mathrm{~K}$, the blow-off observed at $90 \%$ of FGR ratio. The NOx concentration drastically reduced to $13 \mathrm{ppm}$ at $0 \%-\mathrm{O}_{2}$ for $86 \%$ of FGR ratio with $600 \mathrm{~K}$ of the preheating diluted air. This indicates that DME has a high possibility of reducing NOx emission by means of FGR. Such characteristic may be due to the high burning velocity and the low auto-ignition temperature.

The NOx reduction ratio relative to the case without FGR is shown in Fig.7. All the

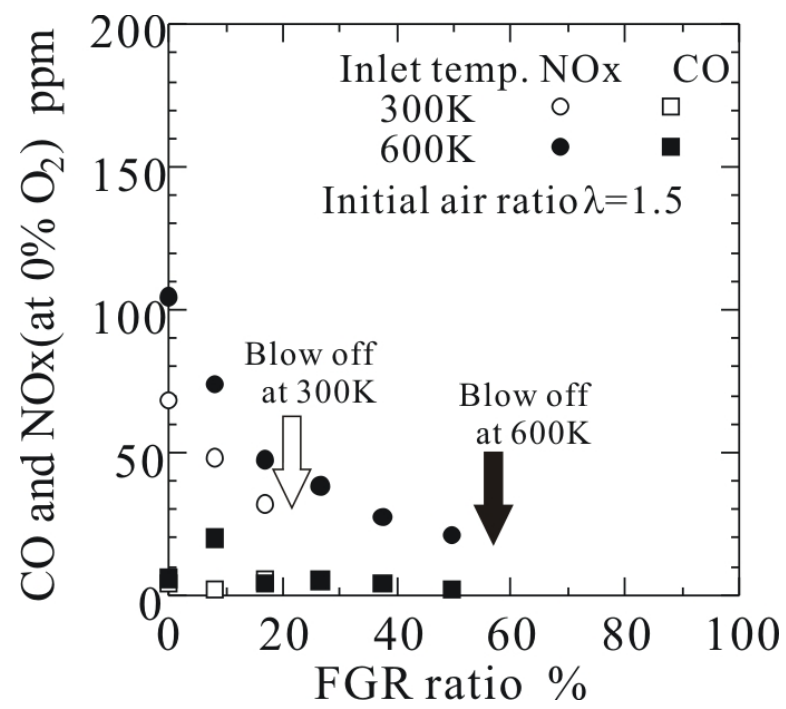

Fig.5 Effect of FGR on flue gas concentration for city gas combustion, $\lambda=1.5$.

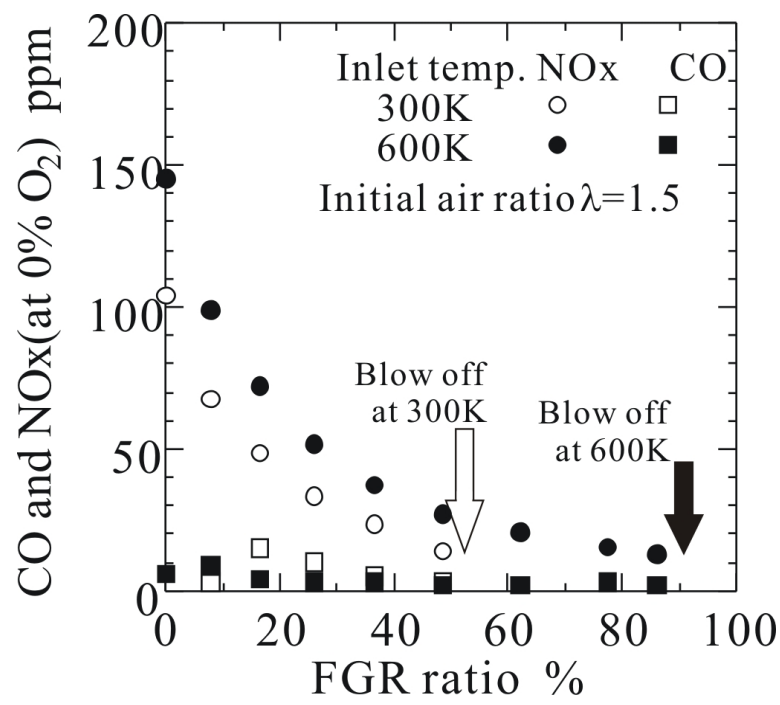

Fig.6 Effect of FGR on flue gas concentration for DME combustion, $\lambda=1.5$. 
experimental data falls into a single curve. DME is applicable even up to the high FGR ratio of $90 \%$, and the NOx emission reduced about $9 \%$ of that at $0 \%$ of FGR ratio.

The blow-off limits of the flame are plotted in the relationship between the $\mathrm{O}_{2}$ concentration and the inlet temperature of the diluted air in Fig.8. The open dot shows the stable flame and the solid plot shows the blow-off. The stable combustion is realized in the left-side area of the blow-off limit expressed by solid lines. The blow-off limit is a function of the oxygen concentration of diluted air independent of the air ratio. By preheating the diluted air, the stable combustion range becomes wide. DME has a wider stable combustion range than that of the city gas. The auto-ignition temperature of DME is $623 \mathrm{~K}$, which is lower than that of methane, 923K. If diluted air is preheated over the auto-ignition temperature of DME, the stable combustion will be sustained even in the low oxygen concentration.

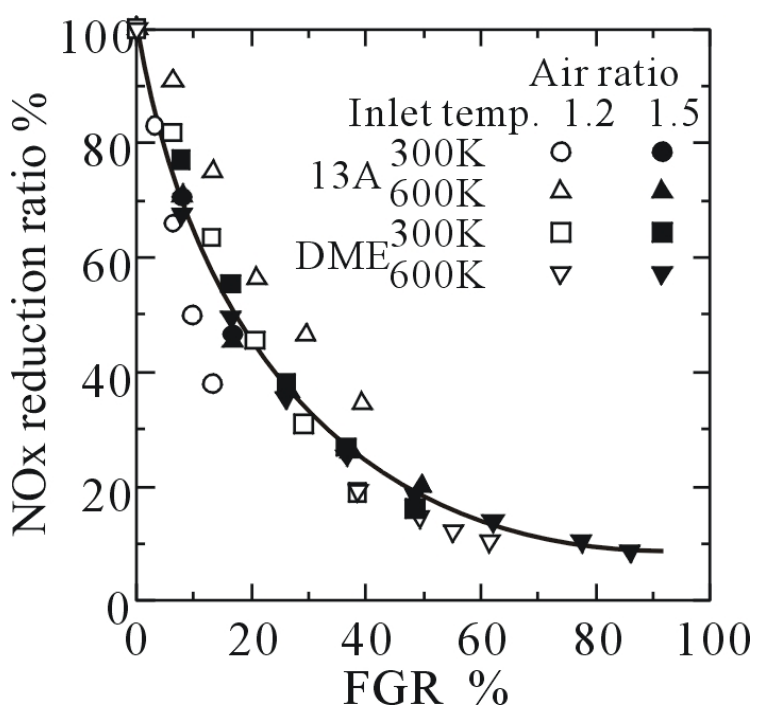

Fig. 7 NOx reduction ratio for $11 \mathrm{~kW}$ combustion test.

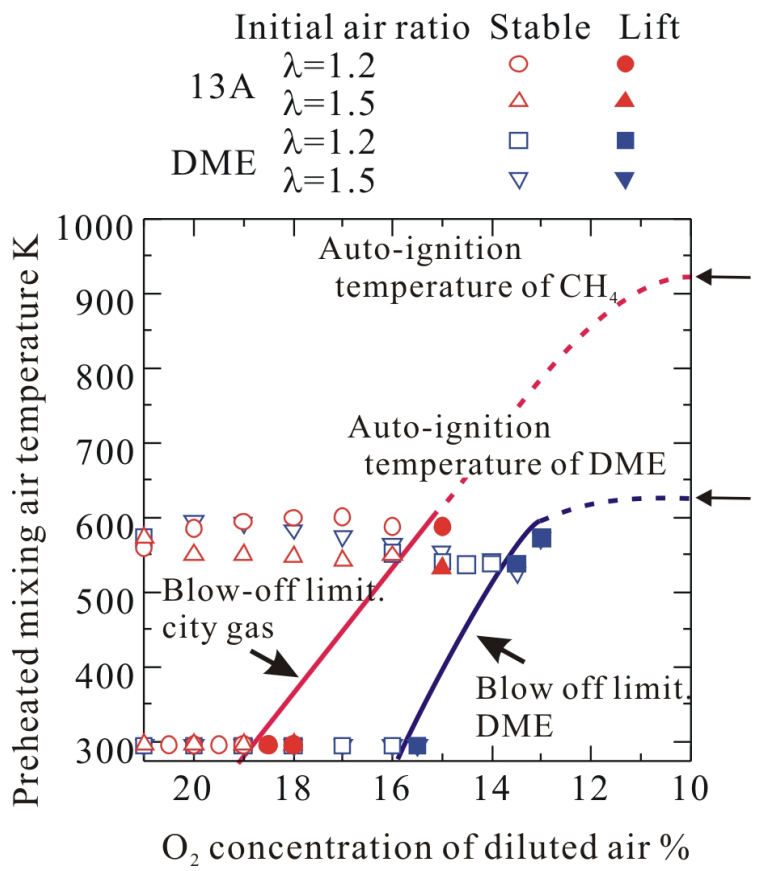

Fig.8 Stable combustion range. 


\section{Industrial Scale Test}

On the basis of the laboratory-scale $11 \mathrm{~kW}$ combustion test, the flue gas recirculation was applied to the demonstration of $700 \mathrm{~kW}$-class (1ton/hour steam output) and 7MW-class (10ton/hour steam output) DME boilers. These two boilers have been developed by

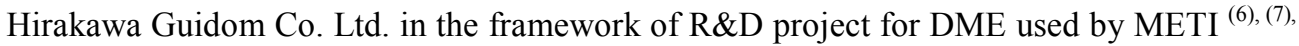
${ }^{(8)}$. The detailed description is found elsewhere ${ }^{(9)}$. Fundamental design of these boilers is based on the tube-nested combustion aiming at the effective low-NOx combustion. The tube-nested combustor ${ }^{(10)}$ consists of the water tubes in its furnace to cool the burning flame directly in the field of burning reaction. Agitation of the burning flame with the installed water-tube-nest enhances combustion and brings about a uniform flame temperature distribution leading to further NOx reduction. Further detailed description on the tubenested combustor was described in the previous report ${ }^{(7)}$.

The developed 700kW-class DME-boiler, as shown in Fig.9, is equipped with a multiport diffusion burner, which has the same structure with that of $11 \mathrm{~kW}$ test. The flue gas is recirculated into the inlet of draft fan. Figure 10 shows the structure of the $700 \mathrm{~kW}$-class test boiler. The water tubes are placed closely to the burner, so that the conventional empty furnace is, in principle, removed. The finned tubes are located in the convective heat transfer zone downstream of the combustor. The rate of fuel consumption is $43.2 \mathrm{~m}^{3} \mathrm{~N} / \mathrm{h}$ of DME. The steam pressure is regulated up to $700 \mathrm{kPa}$.

The over view of 7MW-class DME-boiler is shown in Fig.11. This boiler has two burner sections aiming at rather wide turn-down ratio. The multi-port diffusion burners have the same configuration with that of $700 \mathrm{~kW}$-class test boiler. This boiler is a natural

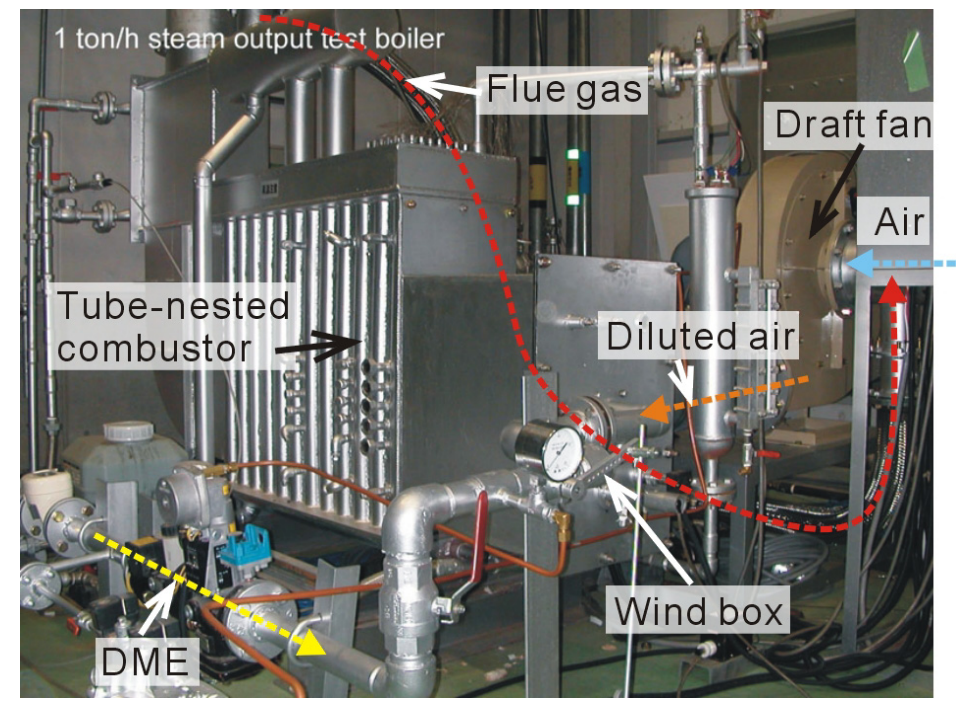

Fig.9 700kW-class test boiler developed by Hirakawa Guidom Co Ltd.

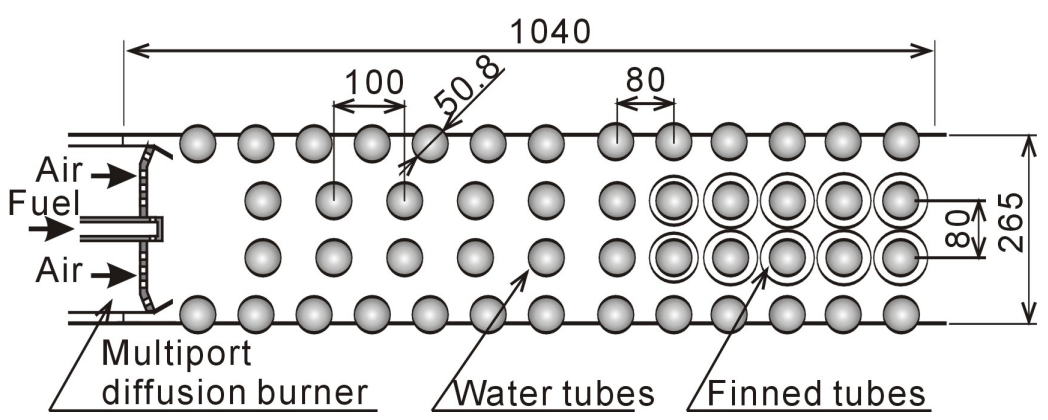

Fig.10 Horizontal cross-section of 700kW-class test boiler with tube-nested combustor. 
circulation type, and the upper steam drum and the lower water drum are connected by water tubes and downcomers. The fuel consumption rate can be changed from 92 to 425 $\mathrm{m}^{3}{ }_{\mathrm{N}} / \mathrm{h}$. The maximum steam pressure is $1.0 \mathrm{MPa}$. On the combustion test, the steam pressure is regulated up to $460 \mathrm{kPa}$.

A series of combustion test was conducted with and without FGR. Figure 12 shows the flue gas concentration without FGR on $700 \mathrm{~kW}$-class test boiler. The NOx emission decreases with an increase in $\mathrm{O}_{2}$ concentration in the flue gas, i.e. an increase of the air ratio $\lambda$. At around the air ratio $\lambda=1.6$, the NOx emission becomes $45 \mathrm{ppm}$ at $0 \%-\mathrm{O}_{2}$, while the $\mathrm{CO}$ emission has a minimum $5 \mathrm{ppm}$. The NOx emission reaches to an acceptable level even by means of the direct flame cooling by the water-tube nest.

The effect of the flue gas recirculation on the NOx emission is plotted as a function of the FGR ratio in Fig.13 for both developed boilers. The curves in the figure represent general trends of $\mathrm{NOx}$ at $0 \%-\mathrm{O}_{2}$ and $\mathrm{CO}$ concentrations, respectively. In addition, the

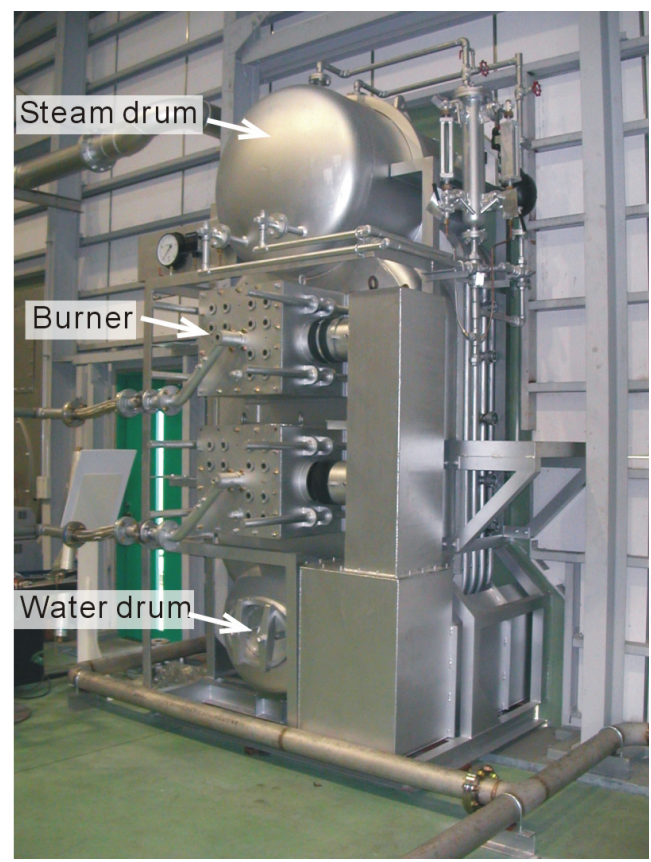

Fig.11 7MW-class natural circulation boiler developed by Hirakawa Guidom Co. Ltd.

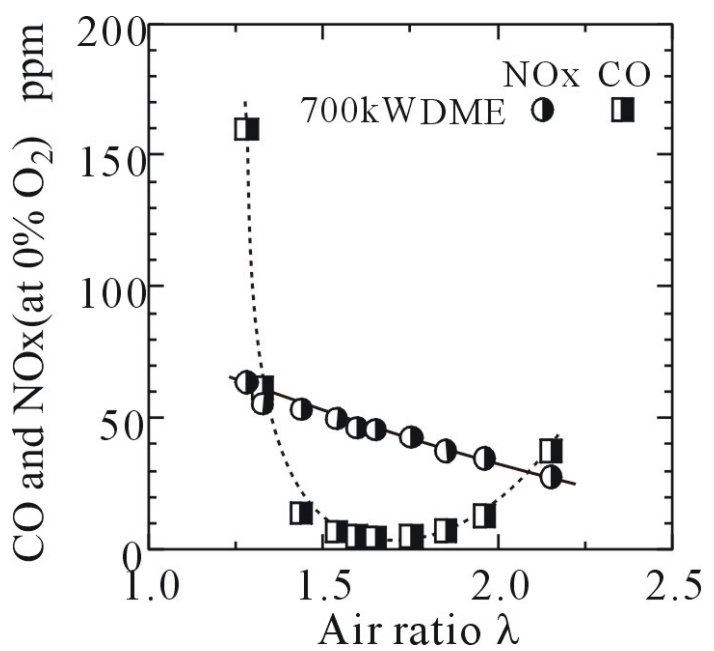

Fig.12 NOx and CO concentration of flue gas without flue gas recirculation (700kW-class boiler). 
horizontal dashed line indicates 10ppm, being the aimed level of NOx emission. The plotted data includes data from $20 \%$ to $100 \%$-load. Throughout these data, the NOx concentration in the flue gas decreases successively with an increase in the FGR ratio, and reaches a very low level, i.e. less than $10 \mathrm{ppm}$ at FRG ratio $=25-35 \%$ of 1 ton-boiler and $30-48 \%$ of 10 tonboiler. On the other hand, the CO concentration in the flue gas increases with FGR ratio due to the cooling of the combustion gas by the water tubes, being different from the case of $11 \mathrm{~kW}$ combustion test. However, the CO concentration is rather low at low FGR ratio, while it increases to about 40-90ppm, being still within an acceptable range. This figure demonstrates a very high potential of NOx reduction by FGR, and even with rather wide turn-down ratio. Such a high percentage of FRG with very low-NOx emission is successfully achieved due to the combustion properties of DME.

Figure 14 shows the NOx reduction ratio for all the results of $11 \mathrm{~kW}$ laboratory-scale combustion tests of $700 \mathrm{~kW}$ and $7 \mathrm{MW}$-class industrial-scale boilers. The data for $11 \mathrm{~kW}$ combustion test is the same with the data in Fig.7. The curves in Fig.14 represent the trend of the NOx reduction. The NOx reduction ratio shows the similar trend in spite of the difference in the burning capacity. The NOx emission drastically decreases with the FGR ratio until about $50 \%$ of FGR, while decreasing moderately over $50 \%$ of FGR and the reduction is almost $10 \%$ compared with the case of NOx emission without FGR.

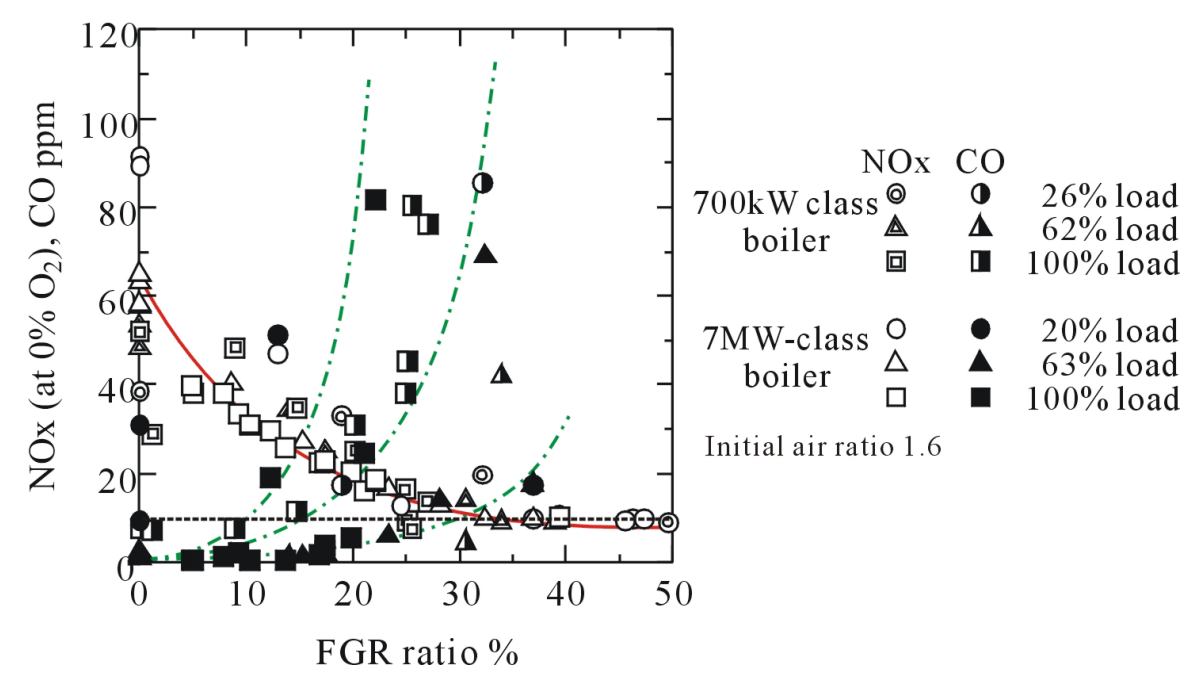

Fig.13 Effect of flue gas recirculation on NOx concentration (700kW and 7MW-class boiler).

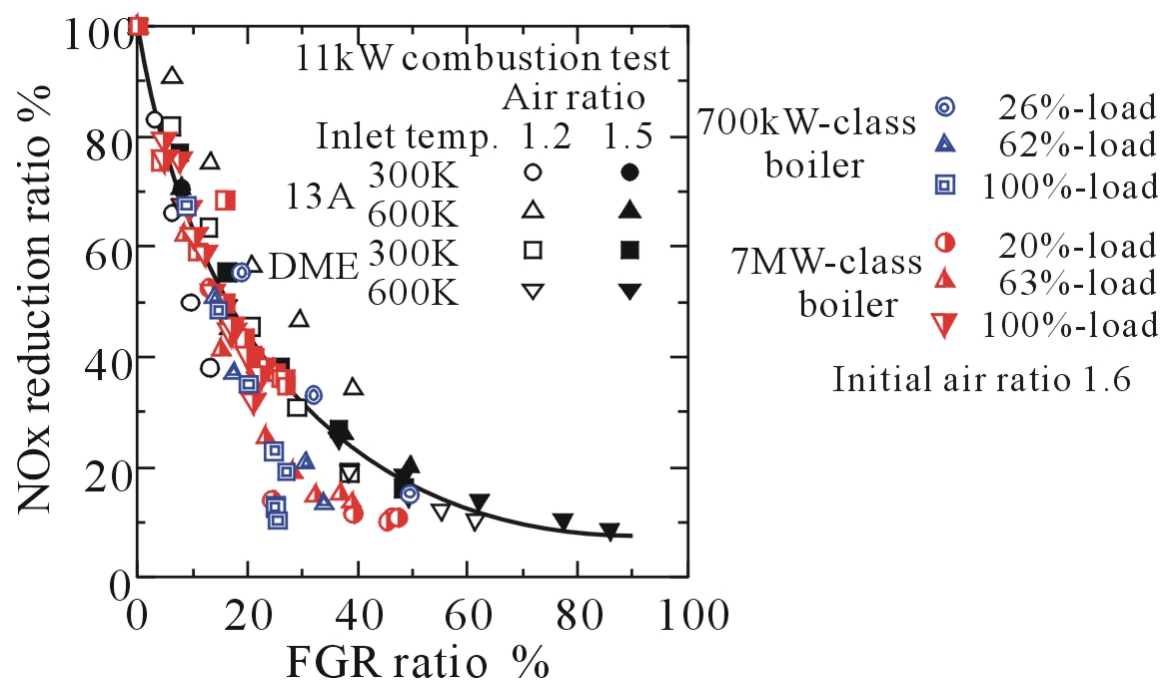

Fig.14 NOx reduction ratio on $11 \mathrm{~kW}$ combustion test, $700 \mathrm{~kW}$ and $7 \mathrm{MW}$-class test boiler. 
This characteristic suggests the existence of a certain similarity law, even though the burning velocity and ignition temperature are constant throughout the different levels of combustion rate in the furnace. In considering such a similarity law, it should be noted that the burner type, i.e. flame holding mechanism and the mixing process of diluted air, is substantially the same throughout the tests.

\section{Conclusions}

This study focuses on the fundamental characteristics of DME combustion with flue gas recirculation. Combustion tests were conducted with laboratory-scale $11 \mathrm{~kW}$ combustor, industrial-scale newly developed DME boilers with $700 \mathrm{~kW}$ and $7 \mathrm{MW}$. The results are summarized as follows:

(1) The flue gas recirculation together with the tube-nested combustor is a very effective means especially for DME in reducing NOx emission drastically while keeping good combustion state and wide turn-down ratio.

(2) The NOx emission is lowered to around or less than 10ppm at high FGR ratio of 25 to $48 \%$ in the industrial scale and $85 \%$ in the laboratory-scale test. Such a high FGR ratio corresponds to decreasing the $\mathrm{O}_{2}$ concentration. This is mainly because of the high burning velocity and low ignition temperature of DME together with the enthalpy recirculation from the flue gas.

(3) In terms of NOx reduction ratio and FGR ratio, there exists a similarity law effective in the larger scale low NOx combustors.

\section{Acknowledgments}

Authors wish to express their sincere thanks to Mr. K. Uchida. This study was conducted under the support by Hirakawa-Guidom Corp. and JFE Holdings, Inc. This research was partly supported by the Kansai University Grant-in-Aid for progress of research in graduate course, 2005.

\section{References}

(1) Ohno, Y., Ogawa, T., Shikada, T. and Inoue, N., DME Production Technology and Operation Results of 5 tons/day Plant, Proceedings of the International DME Workshop, Japan DME Forum, (2000), pp.73-81.

(2) Japan DME Forum, DME Handbook,(2006), pp.30-57, Ohmsha.

(3) Kobayashi, N., Inoue, H., Koizumi, H. and Watanabe, T., Robust design of the coaxial jet cluster nozzle burner for DME (Dimethyl Ether) fuel, Proceedings of ASME Turbo Expo 2003, CD-ROM, (1993), GT2003-38410.

(4) Matsumoto, R., Ozawa, M., Ishihara, I., Sasaki, S. and Takaichi, M., Development of low-NOx DME multi-port burner, JSME International Journal, Series B, Vol.49, No.2(2006), pp.245-252.

(5) Gupta, A. K., Hasegawa, T., Katsuki, M., Kishimoto, K., Morita, M. and Tsuji, H., High Temperature Air Combustion: From Energy Conservation to Pollution Reduction, (2006), pp.1-28, CRC Press.

(6) Ozawa, M., Matsumoto, R., Higuchi, N., Hayashi, Y., Uematsu, H. and Suita, Y., Low NOx Combustion Technology for DME-Fired Water-Tube Boiler, First International DME Conference -Conference Documentation-, (2004), 7B-3.

(7) Ozawa, M., Matsumoto, R., Higuchi, N., Hayashi, Y., Uematsu, H. and Suita, Y., DMEFired Water-tube Boiler - A R\&D Study, JSME International Journal, Series B, Vol.49, No.2(2006), pp.253-259. 
(8) Ozawa, M. and Matsumoto, R., R\&D study for DME-fired low-NOx boiler, 2nd International DME conference -Conference Documentation-, (2006), 7b-2.

(9) Seko, T., Matsumoto, R., Shintani, Y., Ishihara, I. and Ozawa, M., Diffusion Combustion in a Tube-Nested Combustor, JSME International Journal, Series B, Vol.47, No.2(2004), pp.207-213.

(10) Ueda, Y., Ishigai, S., Ozawa, M., Kurimoto, K., Hasebe, H., Okada, H., Kaminashi, A., Kinoshita, M. and Yamamoto, M., Experimental Study of a New Type Boiler with Tube-Nested Combustor, Proceedings of ICOPE'95 Shanghai, (1995), pp.357-362. 